\title{
HEARD BUT NOT NECESSARILY SEEN: SURVEYS OF BIRDS AT GREENWATER AND MOOSE MOUNTAIN PROVINCIAL PARKS
}

FRANK SWITZER, 1301 Shannon Road, Regina, Saskatchewan. S4S 5K9

In June of 1993 I indulged in an exceedingly pleasant activity. I am referring to a mentally refurbishing activity called bird listening which is not to be confused with bird watching. In the latter activity one remains squinty eyed, continually scanning like radar, lest some silent passer-by be missed. Bird listening, on the other hand, allows for conformity to a natural borne disposition on my part, to indulge, in apparent lassitude, eyes closed, to hear more acutely the objects of interest. Common to both activities is the birder's affliction, twitching. For the uninitiated, twitching refers not to random movements related to slumber, but to the act of marking a checklist with each new species seen or heard.

Through a Nature Saskatchewan

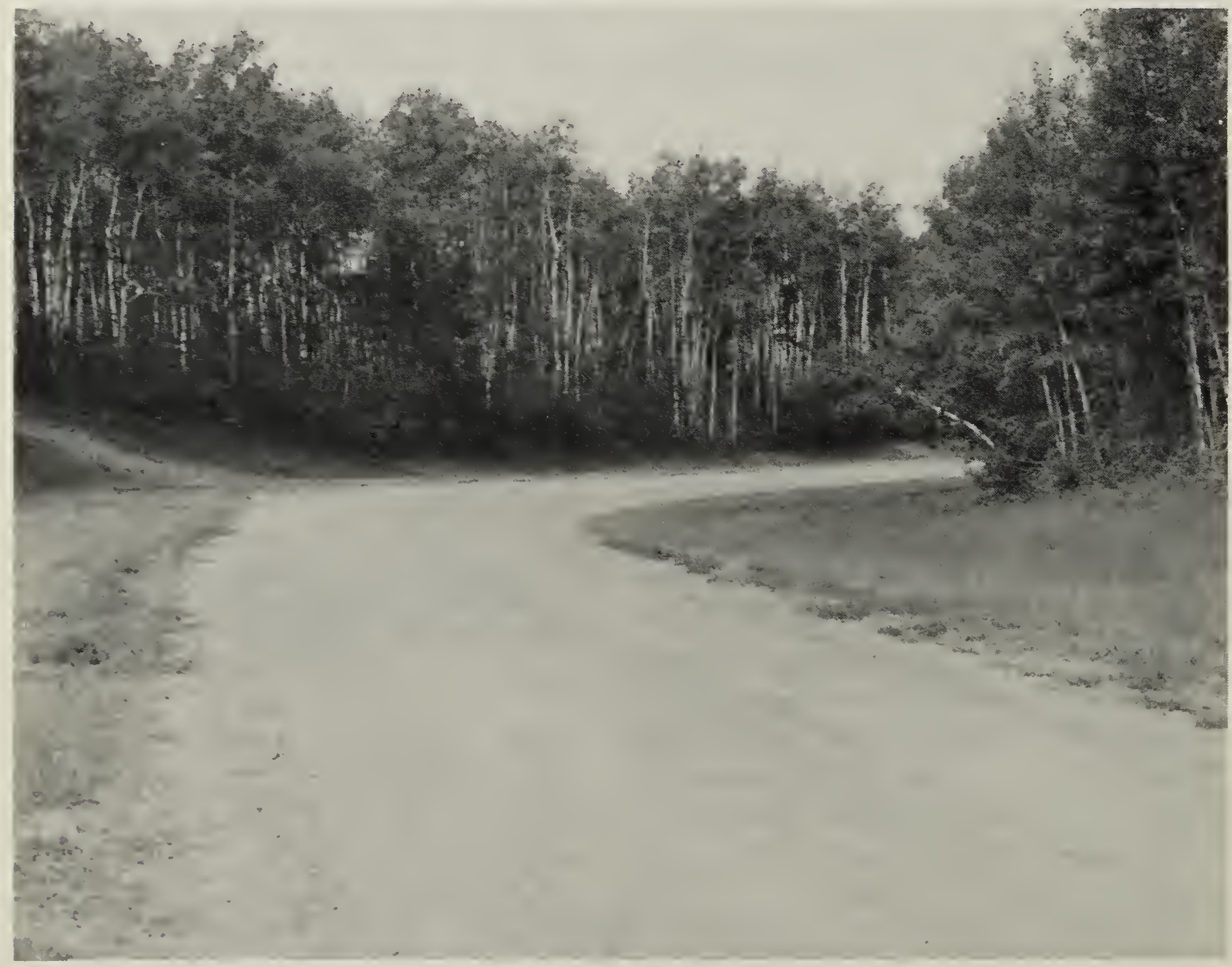

Photo 1. Typical road fringe habitat found along the Grid Road at Greenwater. 


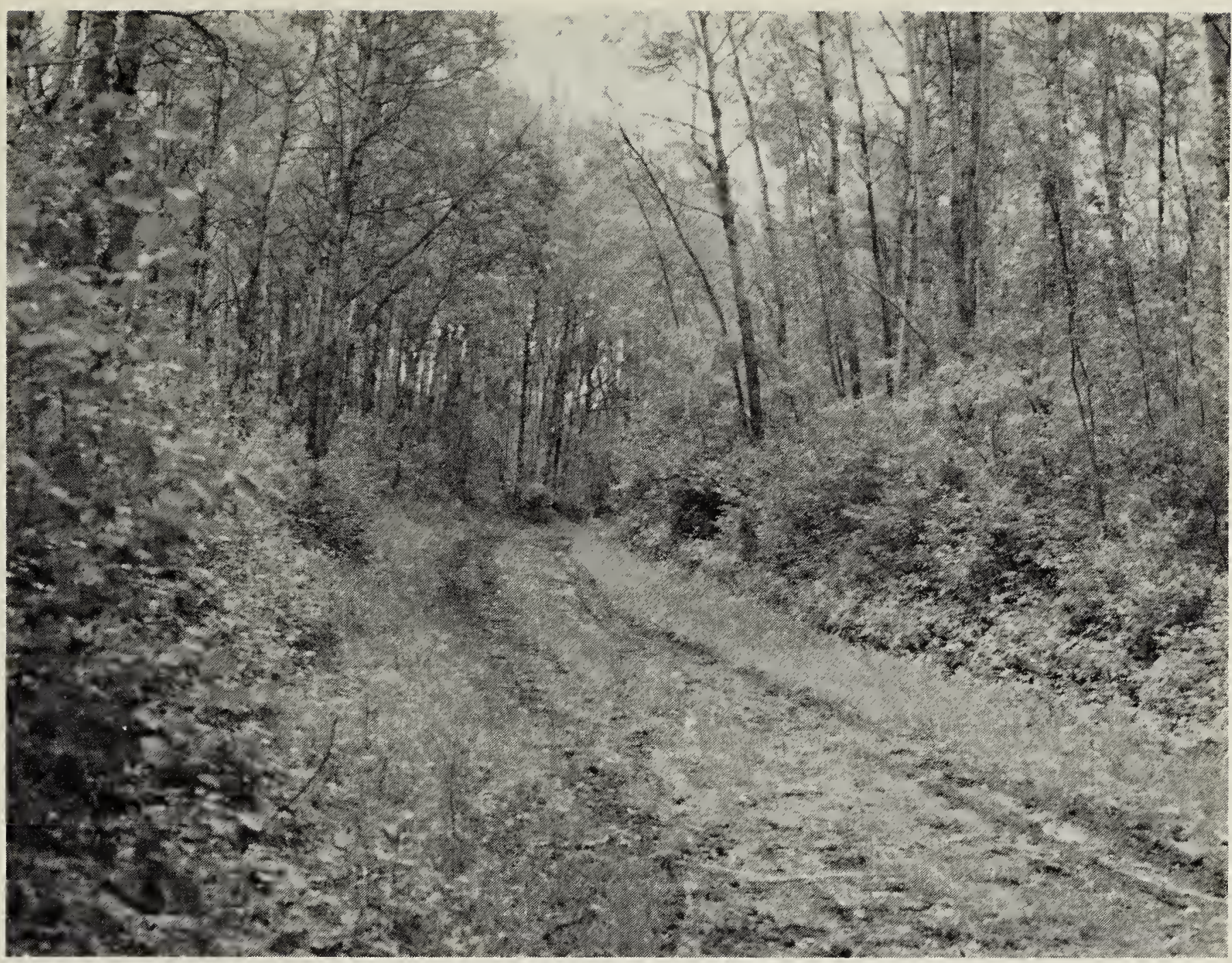

Photo 2. Stewart Lake trail at Moose Mountain. It is similar habitat to that along the Gillis Lake road at Moose Mountain and the Tower Road at Greenwater.

Frank Switzer

Member Initiative, I undertook a project to conduct breeding bird surveys in two provincial parks. The information was collected to help assess vegetation management practices being used in Greenwater and Moose Mountain Provincial Parks, namely clearcut and selective cut logging.

The weather of June 1993 was not the kindest with respect to undertaking breeding bird surveys. Of the month's thirty days, if you remember, there were only seven mornings with conditions marginally satisfactory for conducting any kind of a breeding bird survey. I consider myself lucky to have been able to use three of those seven relatively windless and rain-free days. However, on two of the three I had to resort to wearing ski pants. Starting at four o'clock in the morning with temperatures in the $0-+5^{0}$ Celsius range was, to say the least, a knee-chilling experience.

In Greenwater Provincial Park, vegetation management is in aspen forest where trees were severely stripped of bark and branches by a hail storm in 1991. The most severe damage is in about a kilometre-wide strip north and northeast of the lake. Within this strip, aspen show poor regeneration. Sample sites were selected in undamaged, slightly damaged and severely damaged uncut forest. Selective cut and clearcut vegetation management locations within the most severely hail damaged area were also sampled.

Representative uncut habitat sampling was performed from a vehicle along the grid road (see Photo 1) from its junction with Highway 38 (sample site \#1 on Map 1) northeast of the park core area, south for 


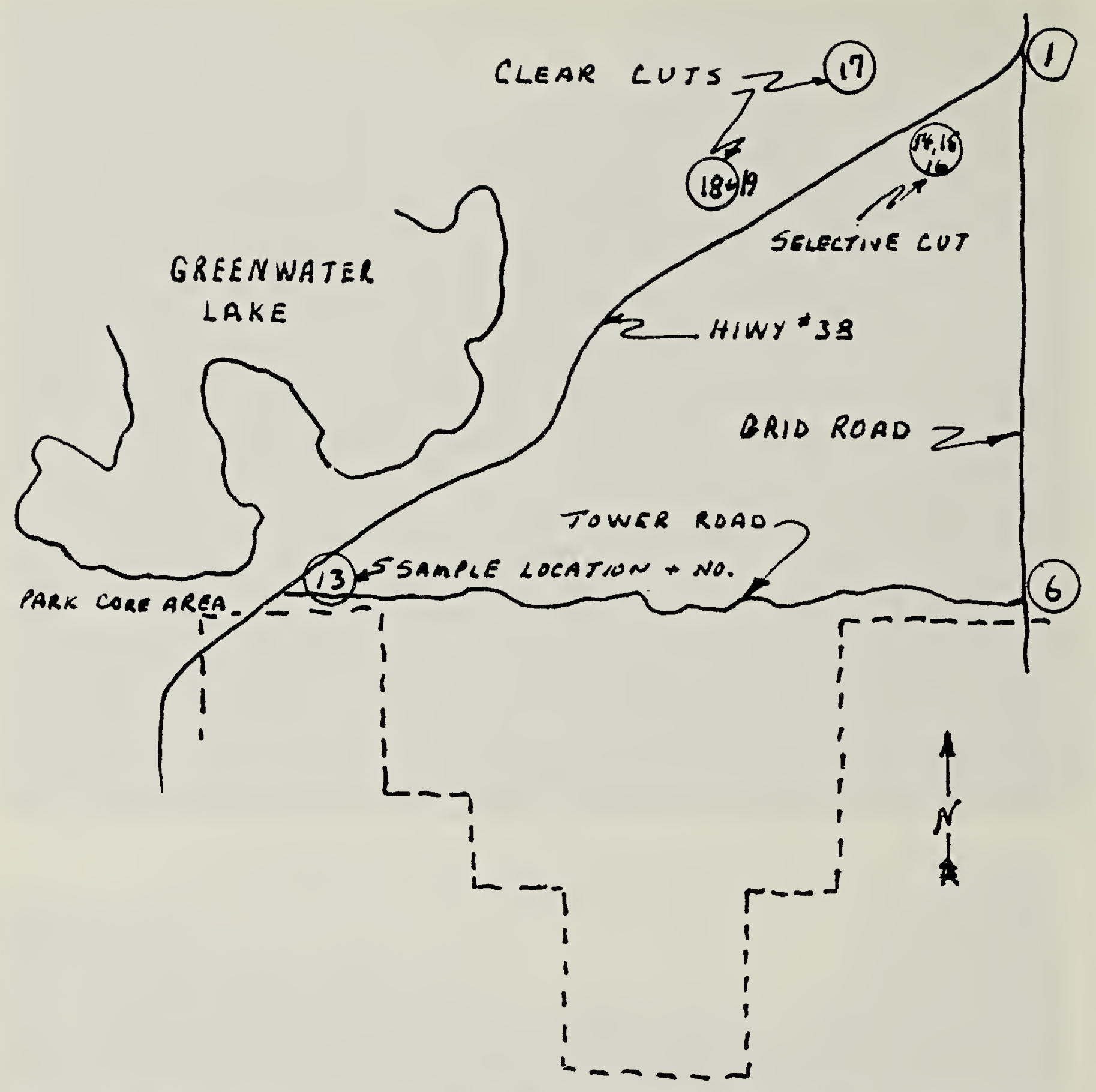

Map 1. SURVEY LOCATIONS IN GREENWATER PROVINCIAL PARK. Frank Switzer

approximately $6 \mathrm{~km}$ and then west along the "Tower Road" to the crosscountry ski trail parking lot (\#13). Thirteen stops at $1 \mathrm{~km}$ intervals were made for sampling purposes. Habitat ranged from hail mutilated to undamaged.

The three cut areas were accessed by foot, each location being visited for a 30-minute period. On the southeast side of Highway 38 in the selective cut, trees have been removed from several narrow meandering strips, covering about 15 ha (\#14, 15, and 16 on Map 1). Found on the northwest side of the highway, the other two cut areas are clearcuts. One is long and narrow, of about 45 ha (\#17 on Map 1); the second is " $U$ " shaped, of about 70 ha (\#18 and 19).

In the selective cut area three samples were taken, one near the southern most area, one in the northern part and one where the access trail branched into the various cuts. Because of good audibility and sample locations not separated by more than $0.5 \mathrm{~km}$, there was some difficulty separating individuals of all species, as to location, within the limited area of the cut. To avoid multiple counts of individuals only one central location should have been chosen. 


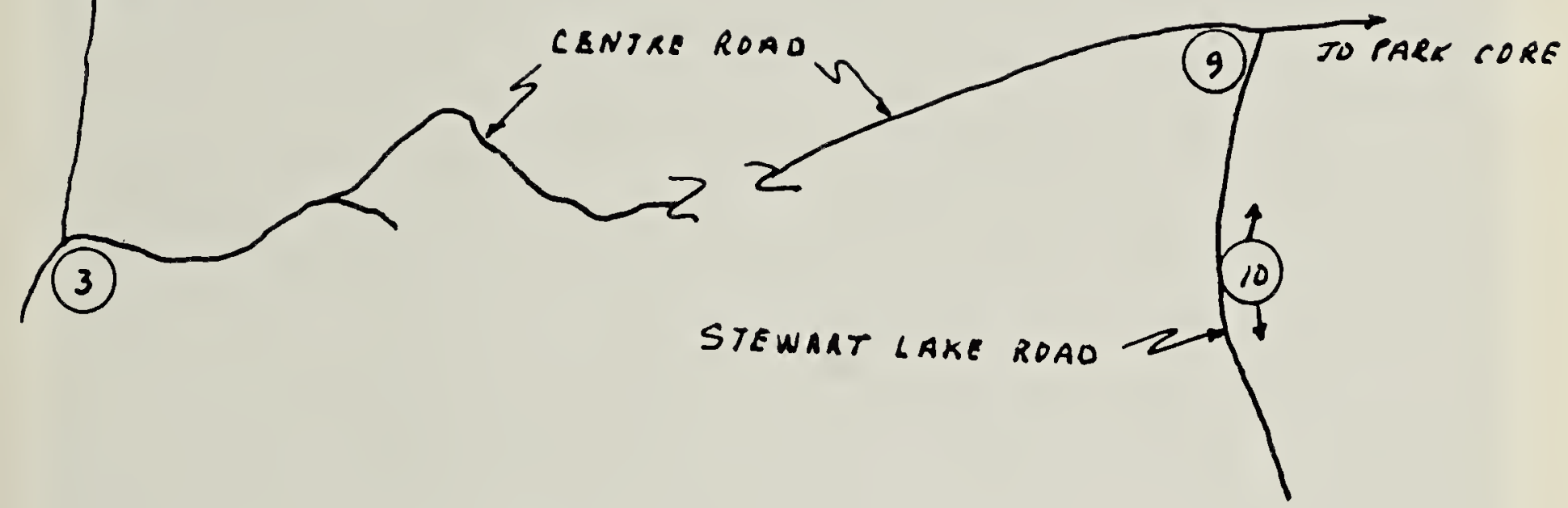

MOOSE MIUNTAIN PROVINCIAC PARK

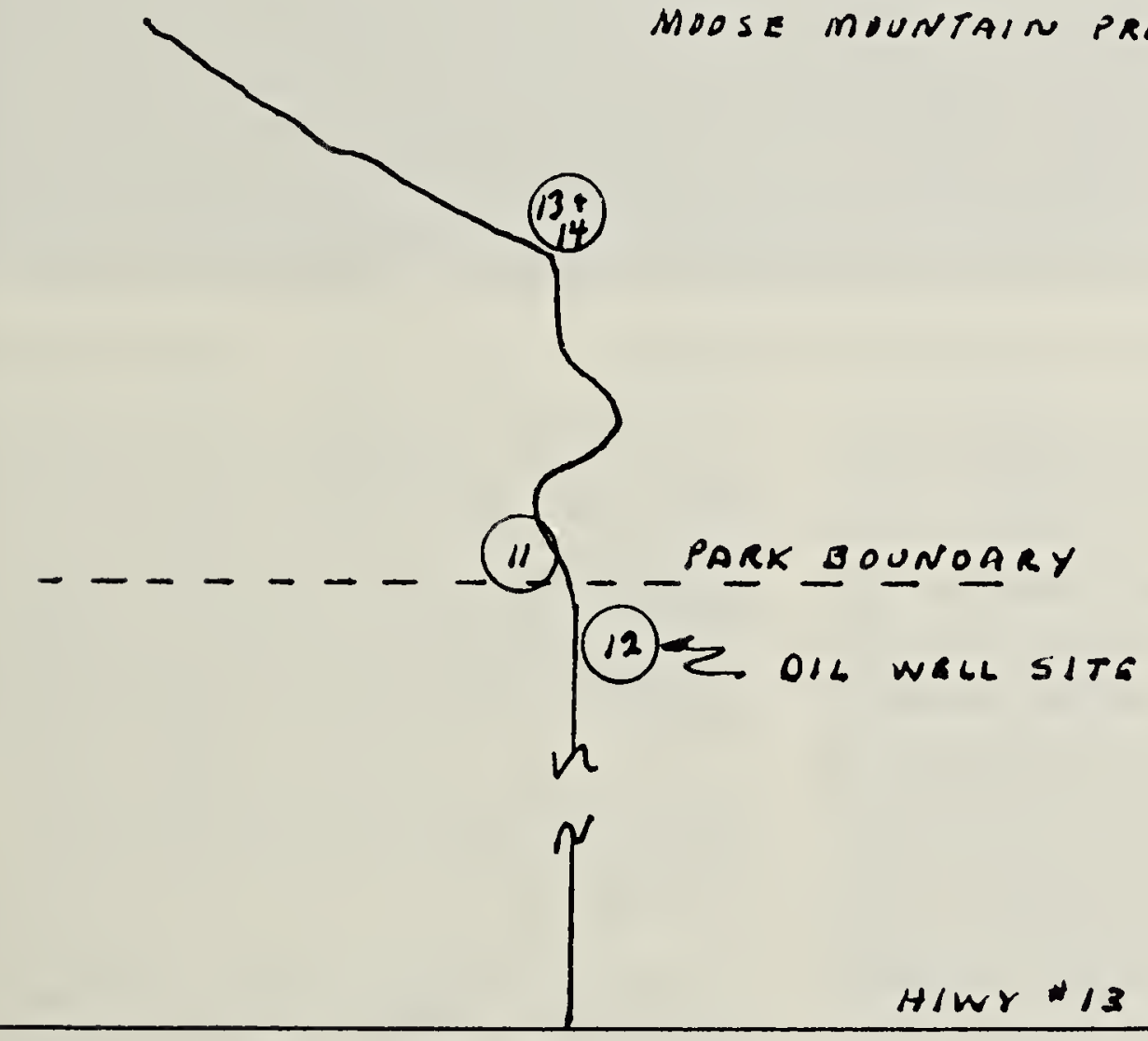

\section{ARCOLA}

Map 2. SURVEY SITES WITHIN AND ADJACENT TO MOOSE MOUNTAIN PROVINCIAL PARK.

Movement through the area gathered a retinue of alarm-calling Whitethroated Sparrows. However, if there had been no movement through the area, I may not have observed the Ruby-throated Hummingbird feeding on the abundant Tall Lungwort (Mer- tensia paniculata).

One sample was taken in the smaller of two clearcuts, about a third of the way down its length. From this location the entire area could be seen and heard. I walked 


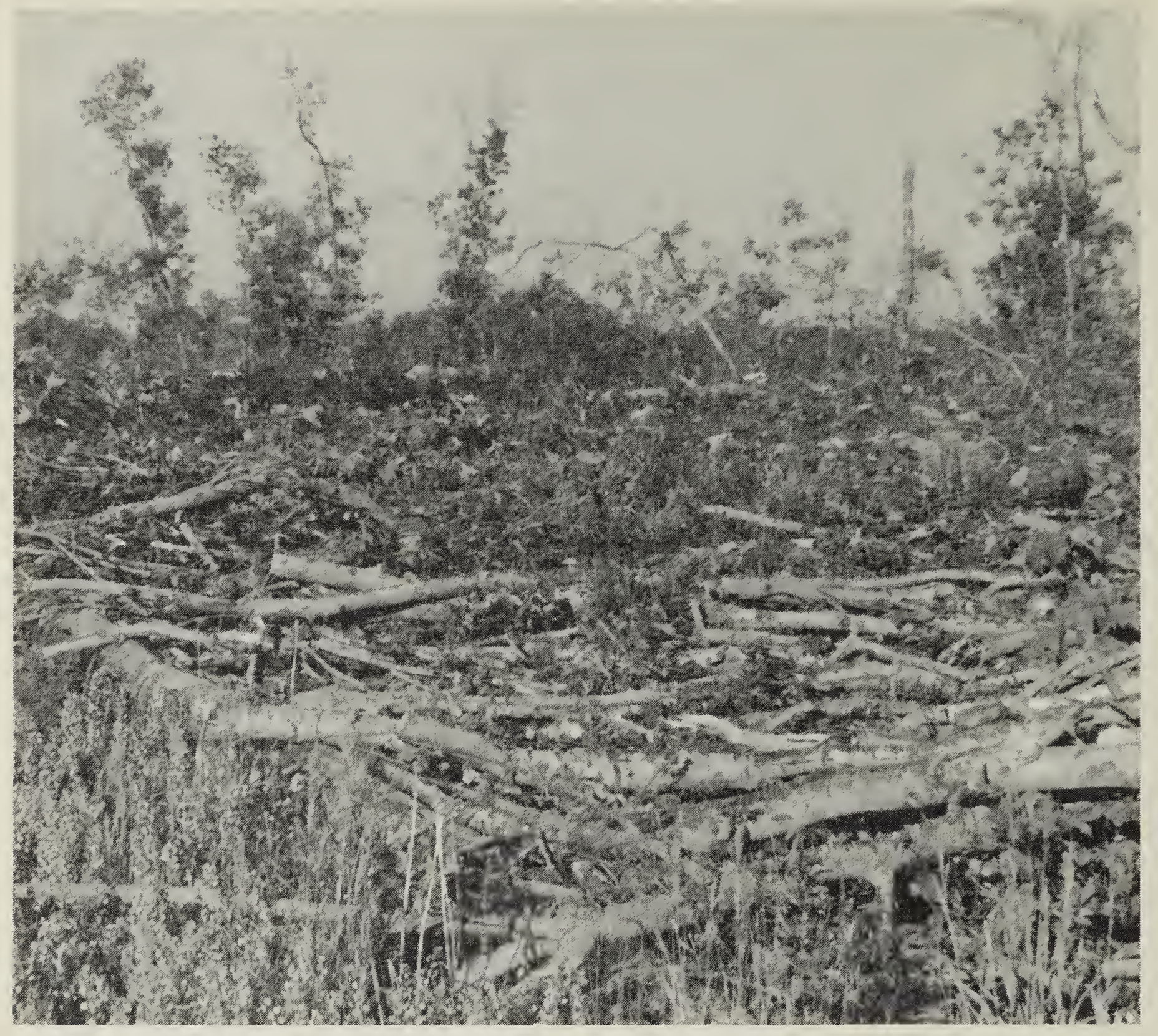

Photo 3. 1992/93 logging area at Moose Mountain.

Frank Switzer

into this clearcut and sat quietly to allow distress calling to subside.

Two samples were taken in the larger "U" shaped clearcut, one on either side of the central area of standing trees. With the exception of two species, the sample locations yielded identical numbers and species. This probably meant all but the two species were double counted. One sampling location would probably have been adequate. Redwinged Blackbirds were the only species seen foraging within the cut area.

The Moose Mountain Provincial Park breeding bird count consisted of 12 sample locations, nine at $1 \mathrm{~km}$ intervals starting on the Gillis Lake road two km north (\#1) of the centre road and along the centre road (\#3 to 9) to the Stewart Lake trail (see Photo 2). The tenth sample was taken during a $1.5 \mathrm{~km}$ walk along the Stewart Lake trail. This trail was impassable to all but four-wheel-drive vehicles. The walk, however, was superb. The density of calling territorial males almost supersaturated my aural sense.

Samples 11 and 12 (Map 2) were taken in an aspen clearcut of about $90 \mathrm{ha}$, approximately $1.5 \mathrm{~km}$ in from the south park boundary north of Arcola. Aspen removal was undertaken during three consecutive winters, with the most recent being harvested in 1992-93 (see Photo 3). Aspen regrowth is prolific. All green ash and a few aspen were not cut so their area is sparsely treed. Most of the cut area can be viewed from the central 


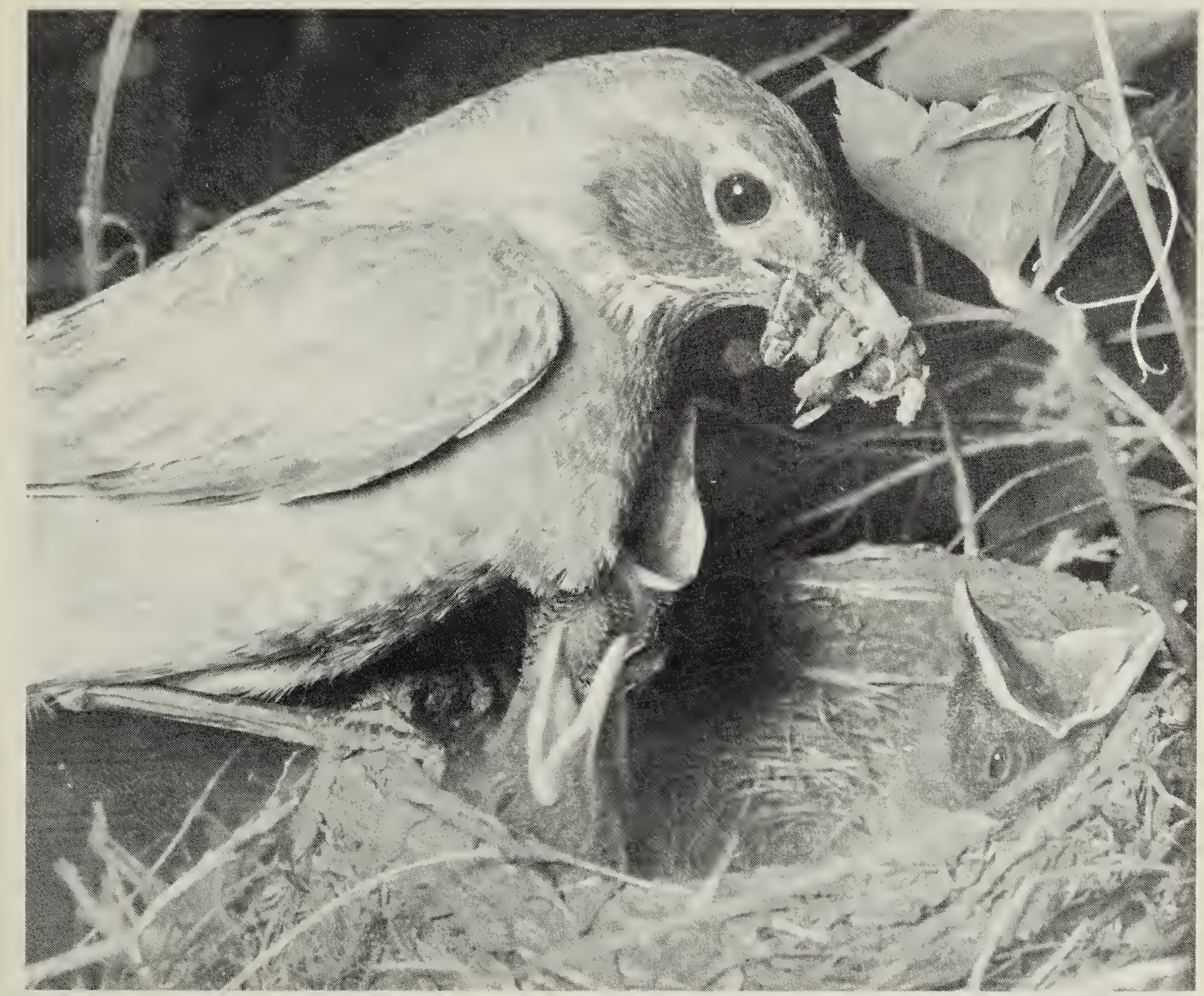

height of land. The sample method chosen for this location was two halfhour sits, one beginning at 6:00 p.m. and the second at 4:45 a.m. the following morning. Species were noted as observed (seen or heard) either in the cut area or in the surrounding aspen forest fringe.

Four species were confirmed as breeding within the cut area. Mourning Doves were nesting on the ground in dense regrowth cover 200 $\mathrm{m}$ southwest of the sample site. Barn Swallows were in the cab of a parked skidder. A House Wren was seen carrying food into a wood pile. A Mountain Bluebird pair were observed feeding young in a woodpecker hole in one of the standing aspen poplars. An American Robin, a Roufous-sided Towhee and a Song Sparrow exhibited strong territoriality within the cut.
Two other samples were taken in the evening - one at the park boundary and one in a four-acre bulldozed oil lease clearing $200 \mathrm{~m}$ south of the park boundary. All species seen and heard at the boundary location appeared to be territorial. All species noted in the area of the bulldozed clearing were at or in the wooded fringe. There did not seem to be any foraging activity within the clearing. These two samples were not officially part of the survey and are not calculated in the listing.

I must confess to one flaw in my bird listening character. I am a technological junky. For the past 30 some odd years I have been making recordings of bird songs. This has been limited by the cost of state of the art cassette recording equipment. About six years ago I started using a Sony Walkman Professional 


\section{Table 1. BIRDS RECORDED AT MOOSE MOUNTAIN AND GREENWATER PROVINCIAL PARKS.}

The number ahead of the " $"$ " indicates the individuals heard or seen; the numbers following indicate the sampling location(s) for each species recorded.

\begin{tabular}{|c|c|c|}
\hline Species & Moose Mountain & Greenwater \\
\hline Common Loon & $1 / 4$ & $1 / 11$ \\
\hline Common Goldeneye & & $2 / 17,19$ \\
\hline Red-tailed Hawk & $1 / 12$ & \\
\hline Sharp-shinned Hawk & $1 / 12$ & \\
\hline Cooper's Hawk & $1 / 12$ & \\
\hline Broad-winged Hawk & $1 / 12$ & \\
\hline Spotted Sandpiper & & $1 / 15$ \\
\hline Ring-billed Gull & $12 / 1$ & \\
\hline Mourning Dove & $5 / 2,8,9,12$ & $2 / 1,2$ \\
\hline Yellow-bellied Sapsucker & & $2 / 6,15$ \\
\hline Downy Woodpecker & $2 / 1,12$ & \\
\hline Hairy Woodpecker & $2 / 1,12$ & \\
\hline Yellow-shafted Flicker & $4 / 2,6,7,12$ & $3 / 14,16,17$ \\
\hline Western Wood-Pewee & & $3 / 10,15,17$ \\
\hline Alder Flycatcher & & $1 / 1$ \\
\hline Least Flycatcher & 35/all sites & $6 / 1,11,15,17,18,19$ \\
\hline Great Crested Flycatcher & $4 / 1,9,12$ & $1 / 9$ \\
\hline Ruby-throated Hummingbird & & $1 / 15$ \\
\hline Tree Swallow & $8 / 4,9,10,12$ & $1 / 12$ \\
\hline Barn Swallow & $2 / 12$ & \\
\hline Blue Jay & $1 / 12$ & \\
\hline Black-billed Magpie & & $1 / 13$ \\
\hline American Crow & & $1 / 13$ \\
\hline Common Raven & & $4 / 13,18,19$ \\
\hline Black-capped Chickadee & $3 / 8,9,10$ & \\
\hline Red-breasted Nuthatch & $1 / 8$ & \\
\hline House Wren & $5 / 1,2,8,10,12$ & $5 / 7,12,15,17,18$ \\
\hline Mountain Bluebird & $2 / 12$ & \\
\hline Veery & 19/all except 7,9 & $9 / 1,8,10,11,19$ \\
\hline American Robin & $16 / 1,2,9,10,12$ & $6 / 1,12,13,16$ \\
\hline Gray Catbird & $1 / 6$ & \\
\hline Cedar Waxwing & $5 / 8,12$ & $5 / 7,12,13$ \\
\hline Yellow-throated Vireo & $1 / 6$ & \\
\hline Warbling Vireo & $9 / 2,7,8,9,10,14$ & $3 / 1,14$ \\
\hline Red-eyed Vireo & $15 / 1,2,3,4,5,10,12$ & 18/all but 4 sites \\
\hline Orange-crowned Warbler & & $1 / 1$ \\
\hline Yellow Warbler & 26/all sites & $5 / 1,8,9$ \\
\hline Chestnut-sided Warbler & $4 / 3,6,7,8$ & $4 / 6,7,8,9$ \\
\hline Black-and-white Warbler & 15/all except 8,9 & $1 / 11$ \\
\hline Mourning Warbler & $1 / 12$ & \\
\hline American Redstart & 27/all sites & $32 / 12$ of 19 sites \\
\hline Ovenbird & $8 / 5,7,8,9,10,12$ & $4 / 2,3,4,5$ \\
\hline Common Yellowthroat & $6 / 6,7,8,9,10,12$ & $2 / 1,3$ \\
\hline Rose-breasted Grosbeak & $1 / 4$ & $2 / 1,5$ \\
\hline Roufous-sided Towhee & $2 / 12$ & \\
\hline Chipping Sparrow & $2 / 12$ & $3 / 2,3$ \\
\hline Clay-colored Sparrow & $1 / 12$ & $4 / 12,13,15$ \\
\hline Savannah Sparrow & $2 / 8$ & $1 / 12$ \\
\hline Song Sparrow & $8 / 2,3,5,6,7,12$ & $3 / 17,19$ \\
\hline White-throated Sparrow & $7 / 5,9,10,12$ & $51 / 17$ \\
\hline Red-winged Blackbird & $7 / 2,9,10$ & $4 / 2$ \\
\hline Yellow-headed Blackbird & $2 / 10$ & \\
\hline Brown-headed Cowbird & $10 / 2,3,5,8,10,13$ & $4 / 3$ \\
\hline Northern Oriole (Baltimore) & $5 / 2,6,8,12$ & $5 / 5$ \\
\hline American Goldfinch & $12 / 8,9,12$ & $3 / 2$ \\
\hline
\end{tabular}




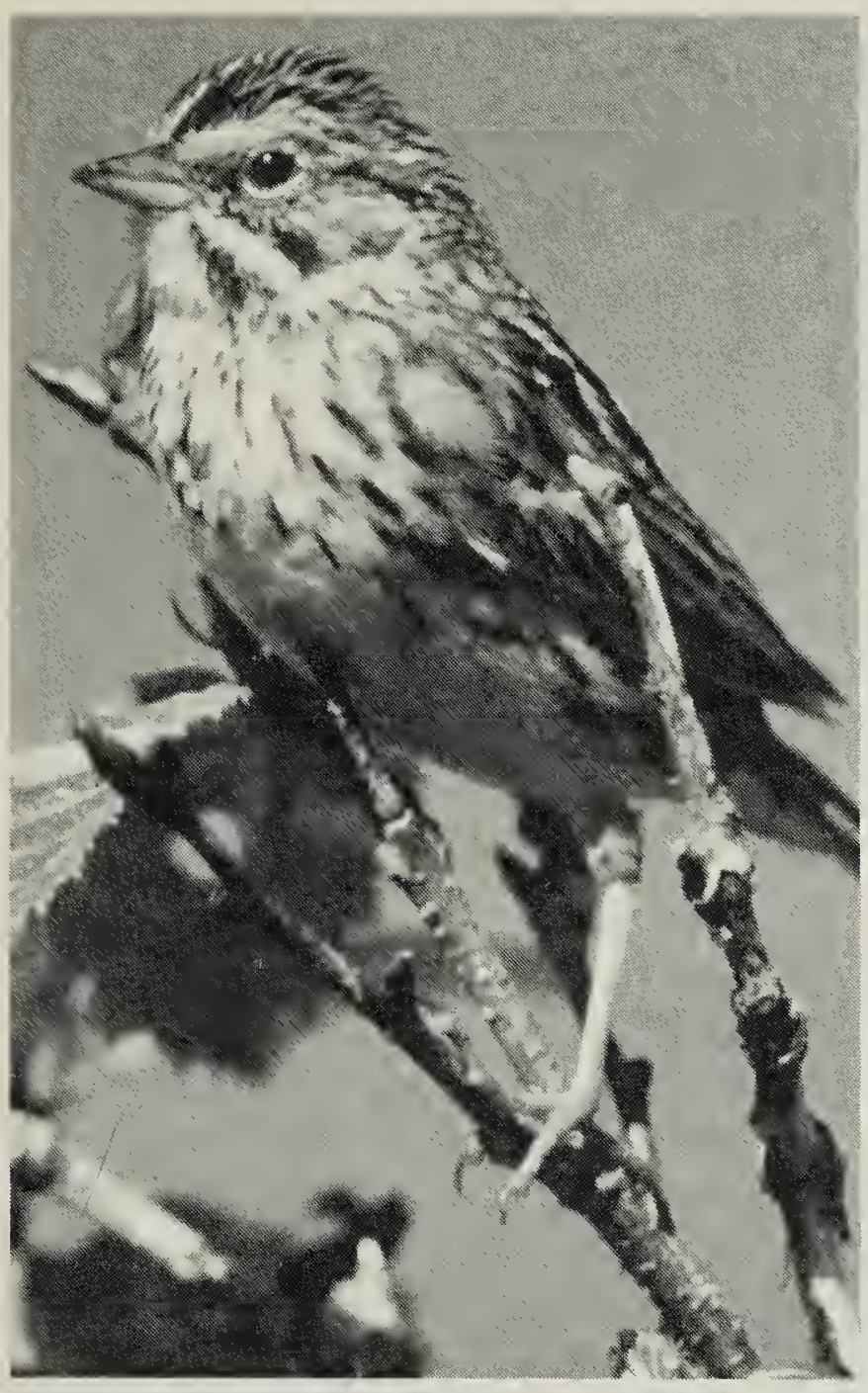

Savannah Sparrow

Wayne Lynch

model WM-D6. This portable piece of equipment has specifications rivalling the best component stereo model and has provided me with excellent aural memories. This year I graduated to a laser minidisk recorder, Sony model MZ-1. Its sound recording capability is phenomenal, 20 to $20,000 \mathrm{~Hz}$ absolutely flat response. It has a fidelity that is only limited by the quality of the play-back audio system.

I tried out this new recording technology during the survey at Moose Mountain Provincial Park. After recording species heard the conventional way, I took an extra three minutes at each stop to digitally record the soundscape. I used matched microphones in two parabolic reflectors aimed to cover opposite directions of the sample sites. The results are exciting. Some refinements are needed, but I see significant potential for breeding bird data gathering via this method. Indications are that computer analysis of this digitally gathered data is not far off.

I have a couple of other observations to share. First, while sitting and observing the oil lease clearing at Moose Mountain, two buck Whitetailed Deer walked across the clearing to within $50 \mathrm{~m}$. They went about their evening browsing activities, taking their time to sample vegetation and move on to places only a deer would know. The second, a magnificent creature, a bull Elk, was on the grid road, at Greenwater. It was a great sight, metrelong rack stubs in velvet. Damn, 4:15 a.m., overcast, not enough light for photos.

Table 1 summarizes the two surveys. The total species count for Moose Mountain was 44; for Greenwater it was 36 .

Since this survey is the first, one can draw few conclusions. However, it would appear that there may not be a significant differences in species, their distribution and density comparing clearcut fringe and road allowance fringe. Bear in mind that all cuts sampled are adjacent to or within $1 \mathrm{~km}$ of existing road rights of way. The species recorded on the survey in Greenwater are reconcilable with those documented for the area in Donald F. Hooper's book, Birds of East-Central Saskatchewan. At Moose Mountain there was species compatibility with the park's bird checklist. 